Far Eastern Entomologist

\begin{tabular}{lll}
\hline Number 426: 10-18 & $\begin{array}{l}\text { ISSN 1026-051X (print edition) } \\
\text { ISSN 2713-2196 (online edition) }\end{array}$ & March 2021 \\
\hline
\end{tabular}

https://doi.org/10.25221/fee.426.2

http://zoobank.org/References/274C1717-CA50-475A-978A-8800FB4463B7

\title{
YEARLY AND SEASONAL CHANGES IN SPECIES COMPOSITION OF HORNETS (HYMENOPTERA: VESPIDAE) CAUGHT WITH BAIT TRAPS ON THE SEA OF JAPAN COAST
}

\author{
K. Kudô $\hat{0}^{1, *}$, W. Oyaizu ${ }^{1)}$, R. Kusama ${ }^{1)}$, K. Yamagishi ${ }^{1)}$, \\ Y. Yamaguchi ${ }^{1)}$, S. Koji ${ }^{2)}$
}

1) Laboratory of Insect Ecology, Faculty of Education, Niigata University, Niigata 9502181, Japan. *Corresponding author.E-mail:kudok@ed.niigata-u.ac.jp

2) Laboratory of Insect Ecology, Graduate School of Science and Technology, Niigata University, Niigata 950-2181, Japan.

Summary. Hornets belong to the genus of Vespa, and are potentially effective predators of insect pests in forests and other environments. To assess the potential impact of prey foraging by the Vespa species, studies have attempted to understand species composition of hornets caught with bait traps in several regions in Japan. These studies showed that the species composition of hornets was different among the different regions in Japan, possibly due to the differences in the geographical distribution and climates. Additionally, the species composition of hornets has only been examined in the inland regions of Japan. In this study, we studied species composition of hornets caught with bait traps in Niigata city on the coast of the Sea of Japan, for a period of four years. The species composition observed in Niigata city was very similar to the composition seen in other temperate, warmer regions, but different from that in subarctic and heavy snowfall regions. There was a single peak in the trap catch due to seasonal changes in the two major species, $V$. analis and $V$. ducalis. There were also yearly changes in the species composition of hornets in Niigata city. The possible causes of the differences among the hornet populations in the seasons and years are discussed in this study.

Key words: social wasps, vespines, ecology, trap catch, environmental differences, Honshu Island, Japan.

К. Кудо, В. Ояйдзу, Р. Кусама, К. Ямагучи, Я. Ямагучи, С. Кодзи. Годовые и сезонные изменения в видовом составе шершней (Hymenoptera: Vespidae), собранных приманочными ловушками на побережье Японского моря // Дальневосточный энтомолог. 2021. N 426. С. 10-18.

Резюме. Шершни рода Vespa являются потенциально эффективными хищниками вредных насекомых лесов и других биотопов. Исследование видового состава собранных приманочными ловушками шершней позволяет сравнить влияние их фуражировки в различных районах Японии. Показано, что видовой состав шершней различен в разных регионах страны и, вероятно, определяется особенностями географических и климатических условий на побережье и в центральных районах Японских островов. Основой настоящего исследования послужили сборы в окрестностях г. Ниигата в течение четырех 
лет. Видовой состав шершней в Ниигате оказался очень сходным с таковым в других умеренно теплых районах, но отличался от северных районов с обильными зимними осадками в виде снега. Для двух наиболее обычных в окрестностях Ниигаты видов $(V$. analis и $V$. ducalis) отмечен один пик численности в течение вегетационного периода. Обсуждаются вероятные причины сезонных и годовых изменений в популяциях шершней.

\section{INTRODUCTION}

Hornets belong to the world-wide genus of Vespa, which consists of 22 species found mainly in the Palaearctic region and tropical southern Asia (Archer, 2012; Smith-Pardo et al., 2020). They are potentially effective predators of insect pests in forests and other environments (Matsuura \& Yamane, 1990). According to Matsuura (1984), all species of hornets are solitary predators except for Vespa mandarinia, which also attacks its prey in groups.

Seven species of hornets are found in Japan, excluding the recent invasive species, $V$. velutina (Ueno, 2014) occurштп in Japan. Hornets can be distinguished as generalists, semigeneralists, and specialists (Matsuura, 1984) because each species displays characteristic prey preferences. Generalists like $V$. analis and $V$. simillima prey on a wide variety of insects and spiders. $V$. crabro, a semi-specialists, forages for a wide variety of insects but prefers a specific group of insects; more than $95 \%$ of the observed prey of $V$. crabro are various cicada species (Matsuura, 1984). Similarly, V. mandarinia preys mainly on coleopterans, including scarabs and longhorn beetles (Matsuura, 1991). Further, V. ducalis is a specialist predator and depend solely on the larvae and pupae of paper wasp (Polistinae).

To assess the potential impact of prey foraging by these Vespa species, previous studies had attempted to understand species composition of hornets caught with bait traps in several regions of Japan. For example, Makino \& Sayama (2005) collected hornets and other vespine wasps during two seasons in two forest parks in Sapporo and Ushiku cities. They showed that $V$. simillima was the dominant hornet species in Sapporo, while $V$. mandarinia and $V$. analis were the most frequently found species in Ushiku. They also examined seasonal changes in the number of hornets, and found that there were two peaks per year in the trap catch of most species in Ushiku, while there was only one peak per year in the trap catch of all species in Sapporo. Oyaizu and Kudô (2013) also examined yearly and seasonal changes in the number of hornets in Tokamachi city. Another aim of studies that obtain information on species composition of hornets is to analyze the level of parasitism in hornets by strepsipterans (Makino \& Yamashita, 1998; Makino, 2001). Makino (2001) collected hornets including stylopized individuals with the use of bait traps during three flight seasons, and examined the impact of the Stylops parasites on the hornet colonies.

Previous studies on species composition of hornets in Japan have provided some interesting information, apart from the different geographical distribution of the species. Makino \& Sayama (2005) compared the species composition of hornets between Ushiku and Sapporo, with temperate and subarctic climates, respectively. They showed that the high number of total catches of $V$. simillima and $V$. dybowskii in Sapporo contributed to a strong difference in the species composition. Similarly, in Tokamachi, with a temperate climate and heavy snowfall during winter, a high number of hornetss of $V$. simillima and $V$. dybowskii species were collected (Oyaizu \& Kudô, 2013). The two common species collected in Sapporo and Tokamachi suggest that environmental conditions may affect hornet communities. However, the number of studies addressing the topic of hornet communities is scarce. In previous studies, the species composition has been examined only in the inland regions of Japan. There were great differences in the richness and composition of ant species between inland and coastal regions in the Niigata prefecture (Yamaguchi, 2009, 2015); thus hornet communities in the 
coastal region may also have characteristic features that differ from those of communities in the inland regions. We studied species composition of hornets caught with bait traps in Niigata city, located on the coast of the Sea of Japan. Additionally, we provided information on yearly and seasonal changes in the species composition of hornets.

\section{MATERIALS AND METHODS}

We monitored hornets in two locations, i.e., Sakata Park (hereafter, SP) (37 $49^{\prime} \mathrm{N}, 138^{\circ}$ $52^{\prime}$ E) and Campus of Niigata University (hereafter, CNU) $\left(37^{\circ} 52^{\prime} \mathrm{N}, 138^{\circ} 56^{\prime} \mathrm{E}\right)$ in Niigata city, central Japan, between 2009 and 2012. These locations were separated from each other by approximately $8 \mathrm{~km}$. Salix babylonia and Celtis sinensis were the dominant tree species in SP, while Pinus thunbergii (Japanese black pines) trees were planted near CNU as a windbreak. Hornets were collected using bait traps which comprised $100 \mathrm{ml}$ of water and an equal amount of grape juice. As bait containers, we used bottles of clear plastic $(2,000 \mathrm{ml}$ in capacity) with a small square hole ( $3 \times 3 \mathrm{~cm}$ in capacity) in the upper part of the bottle.

We set 30 and 22 traps at SP and CNU, respectively, at intervals of 40 to $50 \mathrm{~m}$, mainly along the walking trails. The traps were tied to trees at a height of $1.5 \mathrm{~m}$ above the ground. The traps were visited weekly from May to November each year, to collect the trapped insects and to replenish the bait. The trapped hornets were preserved in $70 \%$ ethanol for identification.

We compared the species composition of hornets in Niigata (i.e. SP and CNU) with that in Sapporo, Ushiku (Makino \& Sayama 2005), Tokamachi (Oyaizu \& Kudô, 2013), and Takaoka city (Makino \& Yamashita, 1998). The analysis was performed using non-metric multidimensional scaling (NMDS), based on Bray-Curtis dissimilarity metrics. The NMDS was conducted using R software ver. 4.0.2 (R Development Core Team, 2020) and vegan package ver. 2.5-6 (Oksanen et al., 2015).

\section{RESULTS}

During the field census for four years, we collected a total of 8,069 and 3,434 wasps of six hornet species in SP and CNU, respectively (Fig. 1). Throughout the four years, $V$. ducalis was the most dominant species in SP, except for 2009, while $V$. analis was the most dominant species in CNU except for 2012. In each year, more than $70 \%$ of the total collection in each location was occupied by the dominant species, except for 2009 in CNU (56\%). The third and fourth largest hornet species collected were $V$. mandarinia and $V$. crabro, respectively. $V$. mandarinia formed $13.09 \%$ of the total collection for SP and $10.54 \%$ of the total collection for CNU, while $V$. crabro formed $5.21 \%$ of the total collection for SP and $7.89 \%$ of the total collection for CNU. In both locations, the number of hornets collected wasps decreased from 2009 to 2010, increased again in 2011, but finally decreased in 2012. Also, species composition differed significantly across the years in both locations $\left(\chi^{2}\right.$ tests, SP: $\chi^{2}{ }_{15}=1473.705, \mathrm{P}<0.001$, CNU: $\chi_{12}^{2}=490.950, \mathrm{P}<0.001$ ).

Figs $2-3$ shows seasonal changes in the number of hornets collected for the two major hornet species, i.e., $V$. analis and $V$. ducalis. In May, overwintered queens were collected for $V$. analis, while the number of overwintered queens was very low for $V$. ducalis. This suggests that the emergence of overwintered queens was later in $V$. ducalis than in $V$. analis. Throughout the four years, the first day that overwintered queens were collected was later for $V$. ducalis than for $V$. analis (Table 1). For $V$. analis, the number of hornets collected was higher in September and October than other months. For $V$. ducalis, the number of hornets collected was the highest in September. In these months, a higher number of males were collected for both species. For $V$. analis, the number of males was higher in October than in September. 
Table 1. First day of collection of overwintered queens for Vespa analis and V. ducalis in the west coast of the Sea of Japan

\begin{tabular}{c|c|c|c|c}
\hline \multirow{2}{*}{ Year } & \multicolumn{2}{|c|}{ Vespa analis } & \multicolumn{2}{c}{ Vespa ducalis } \\
\cline { 2 - 5 } & SP & CNU & SP & CNU \\
\hline 2009 & May 1 & May 8 & May 29 & May 29 \\
\hline 2010 & May 13 & May 8 & May 27 & May 27 \\
\hline 2011 & May 18 & May 13 & June 8 & May 27 \\
\hline 2012 & May 9 & May 9 & May 30 & May 23
\end{tabular}

Abbreviations. SP - Sakata Park; CNU - Campus of Niigata University.

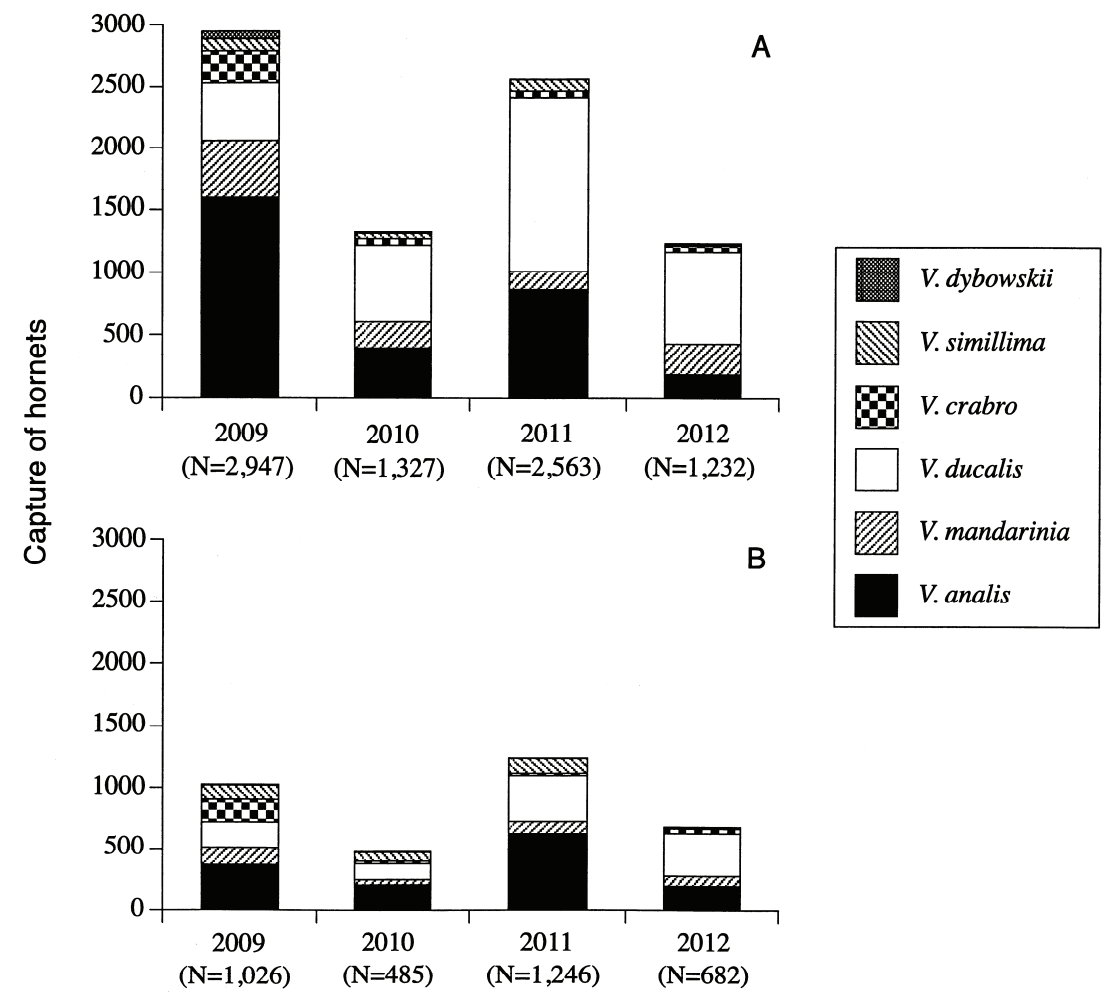

Fig. 1. Yearly changes in the species composition of hornets in Sakata Park (A) and campus of Niigata University (B).

\section{DISCUSSION}

In this study, we characterized species composition of hornets caught with bait traps on the coast of the Sea of Japan. Six hornet species were collected in every year from 2009 to 2012, and three of these species ( $V$. analis, $V$. ducalis, and $V$. mandarinia) were dominant. Seven hornet species have been described in Japan, excluding the recently invasive species, V. velutina (Ueno, 2014). V. affinis is only distributed in the south of the Sakishima Islands (Matsuura \& Yamane, 1990); hence, the remaining six hornet species were collected for this 

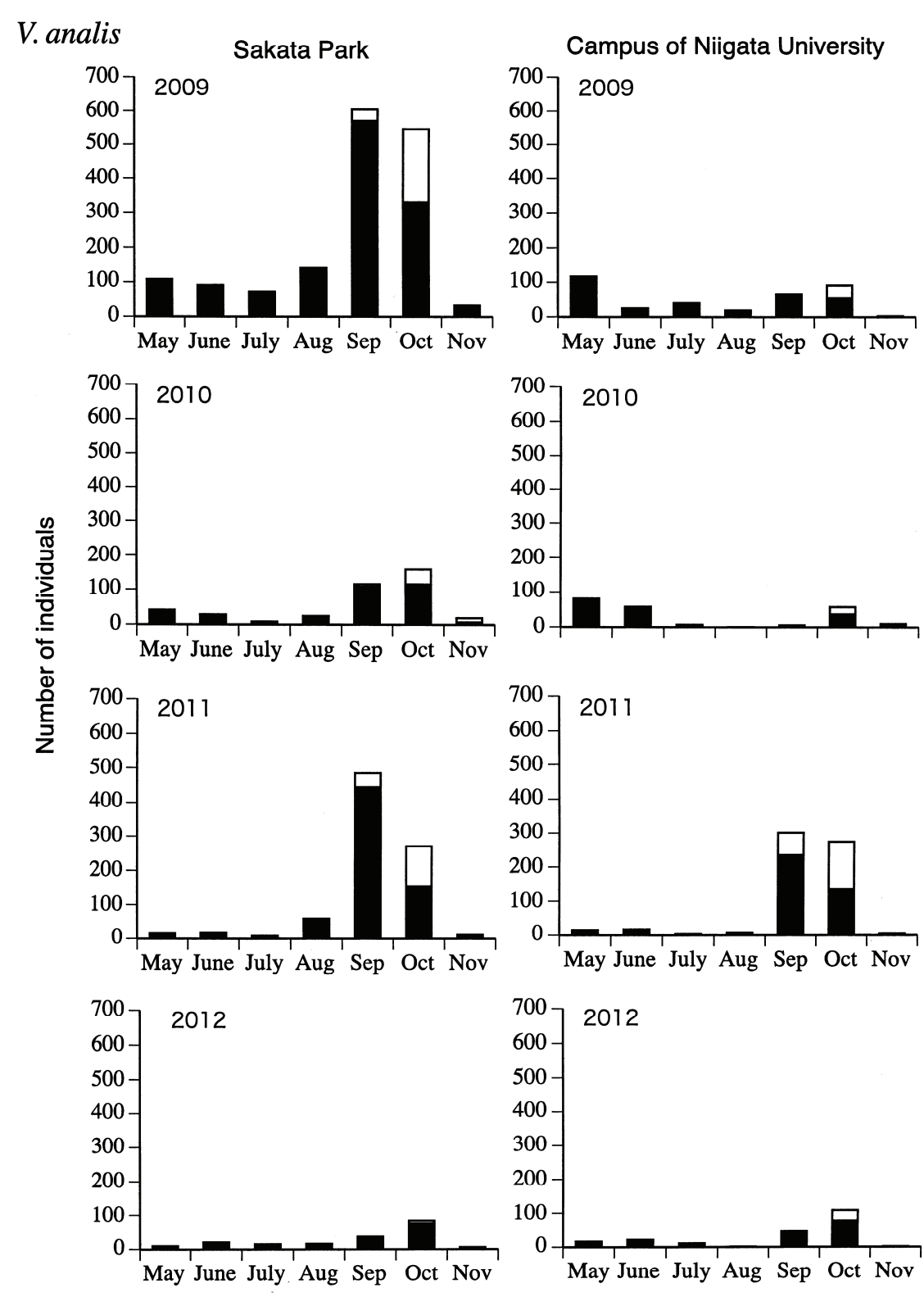

Month

Fig. 2. Seasonal abundance of Vespa analis collected by bait traps at Sakata Park and campus of Niigata University. Clear and shaded bars indicate male and female hornets, respectively. 


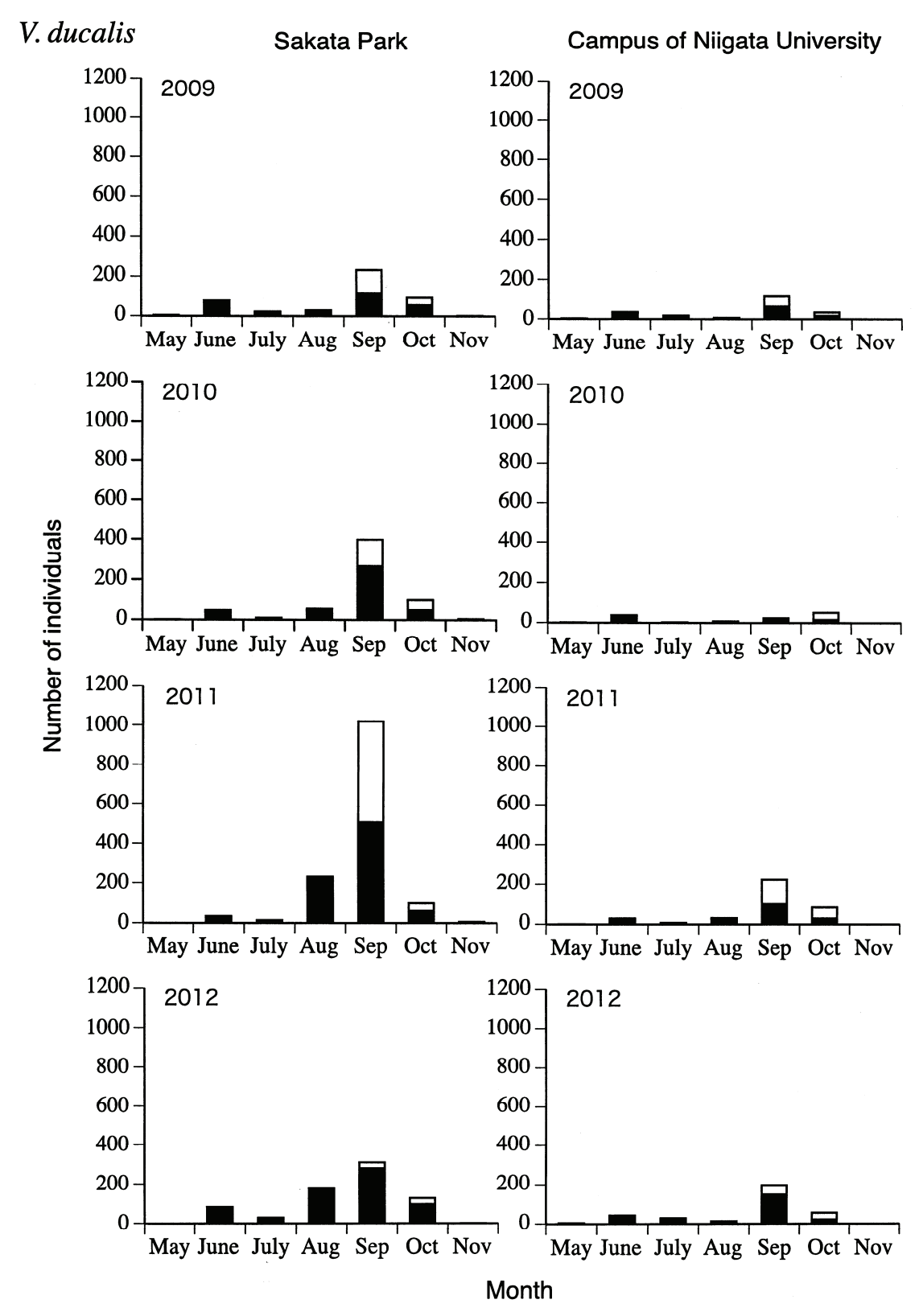

Fig. 3. Seasonal abundance of Vespa ducalis collected by bait traps at Sakata Park and campus of Niigata University. Clear and shaded bars indicate male and female hornets, respectively. 
study. Previous studies did not collect all hornet species with bait traps. For example, four species excluding $V$. crabro and $V$. dybowskii were collected in Takaoka, Miyazaki prefecture (Makino \& Yamashita, 1998) (but note to the non-distribution of $V$. dybowskii in Miyazaki prefecture). Also, Makino (2001) did not collect any individuals of $V$. dybowskii in Ushiku city and Kukizaki town, Ibaraki prefecture, during his study of three years.

Table 2. Dominant hornet species caught with bait traps in Japan

\begin{tabular}{l|l|l|l|l}
\hline \multicolumn{1}{c|}{ Top three dominant species } & \multicolumn{1}{c|}{ Locations } & \multicolumn{1}{c}{ References } \\
\hline V. ducalis & V. analis & V. mandarinia & Takaoka & $\begin{array}{l}\text { Makino \& } \\
\text { Yamashita (1998) }\end{array}$ \\
\hline V. analis & V. mandarinia & V. ducalis & $\begin{array}{l}\text { Ushiku and } \\
\text { Kukizaki }\end{array}$ & Makino (2001) \\
\hline V. simillima & V. dybowskii & V. analis & Sapporo & $\begin{array}{l}\text { Makino \& Sayama } \\
(2005)\end{array}$ \\
\hline V. mandarinia & V. analis & V. ducalis & Ushiku & $\begin{array}{l}\text { Makino \& Sayama } \\
(2005)\end{array}$ \\
\hline V. simillima & V. dybowskii & V. mandarinia & Tokamachi & $\begin{array}{l}\text { Oyaizu \& Kudô } \\
(2013)\end{array}$ \\
\hline V. analis & V. ducalis & V. mandarinia & Niigata & This study \\
\hline
\end{tabular}

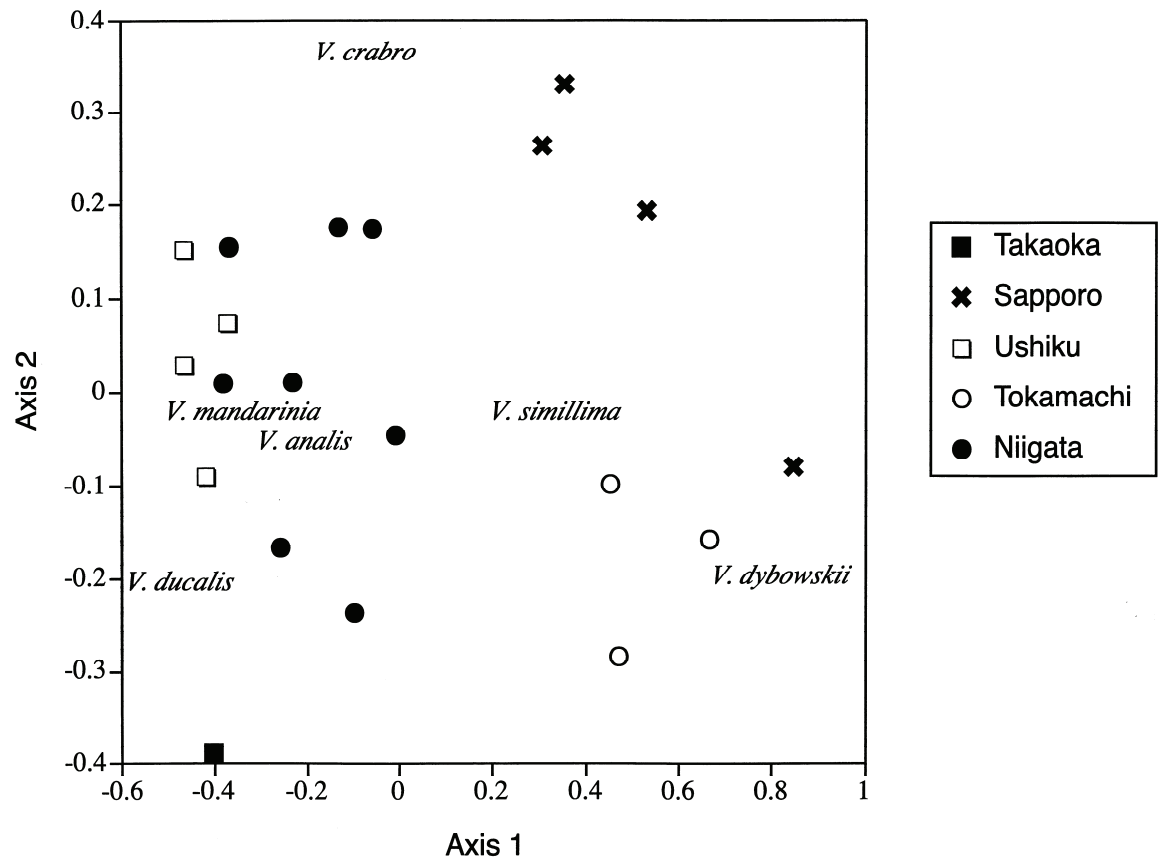

Fig. 4. Nonmetric multidimensional scaling (NMDS) plot comparing hornet species composition among five regions in Japan. The symbols indicate samples of yearly baittrapped collection from study locations in each region. Species scores are shown as texts. 
When comparing the dominant hornet species in coastal Niigata city with those of inland regions (Table 2), the dominant species observed in Niigata city were very similar to other temperate, warmer regions, such as Kanto (Makino, 2001; Makino \& Sayama, 2005) and Kyushu (Makino \& Yamashita, 1998) distinctions. However, the dominant species in these warmer regions were different from those of subarctic (Sapporo) and heavy snowfall regions (Tokamachi). In the latter regions, high number of individuals of $V$. dybowskii and $V$. simillima species was observed (Makino \& Sayama, 2005; Oyaizu \& Kudô, 2013). These interpretations were strongly supported by the NMDS results (Fig. 4), in which a notable difference was observed in the species composition among the different climatic regions.

With seasonal changes, there was only a single peak in trap catch for $V$. analis and $V$. ducalis. In the peak, male and female hornets were collected together, suggesting that these hornets were composed of workers as well as reproductive hornets (males and new queens). Makino \& Sayama (2005) also showed a single peak in the trap catch of vespine wasps in Sapporo and explained that far fewer overwintered queens were caught, than workers. A notable difference in seasonal changes between the two species was the late emergence of hibernated queens and earlier emergence of reproductive hornets (males) in $V$. ducalis. This means that $V$. ducalis has shorter colony cycles, when compared to $V$. analis. Hornets from $V$. ducalis are specialists that forage for pupae and larvae of paper wasps, and hence their life history is known to synchronize with the predated wasps (Matsuura \& Yamane, 1990). Matsuura and Yamane (1990) observed that in the genus Vespa, emergence of hibernated queens is the latest, and the mature colony size is the smallest in $V$. ducalis.

In conclusion, all six described species of hornets were collected with bait traps in a coastal city, Niigata. This suggests that the richness and abundance of insect preys associated with hornets is high even in the coastal area. However, factors affecting population dynamics of these hornet species are unknown in this study. Dynamics of individual hornets and colonies should be analyzed by long-term studies on Vespa species.

\section{ACKNOWLEDGEMENTS}

We thank Sakata Park for granting us permission to undertake vespine monitoring. Two anonymous reviewers kindly commented on earlier drafts of the manuscript.

\section{REFERENCES}

Archer, M.E. 2012. Vespine Wasps of the World: Behaviour, Ecology \& Taxonomy of the Vespinae Siri Scientific Press, Manchester. 352 pp.

Makino, S. \& Yamashita, Y. 1998. Levels of parasitism by Xenos mouton du Buysson (Strepsiptera, Stylopicae) and their seasonal changes in hornets (Hymenoptera: Vespidae, Vespa) caught with bait traps. Entomological Science, 1: 537-543.

Makino, S. 2001. Seasonal changes in levels of parasitism and sex ratio of Xenos moutoni du Buysson (Strepsiptera, Stylopidae) in the Japanese hornet, Vespa analis insularis Dalla Torre (Hymenoptera, Vespidae), collected with attractant traps. Tijdschrift voor Entomologie, 144: 217-222.

Makino, S. \& Sayama, K. 2005. Species compositions of vespine wasps collected with bait traps in recreation forests in northern and central Japan (Insecta, Hymnoptera, Vespidae). Bulletin of FFPRI, 4: 283-289.

Matsuura, M. 1984. Comparative biology of the five five Japanese species of the genus Vespa (Hymenoptera, Vespidae). Bulletin of the Faculty of Agriculture, Mie University, 69: 1-131. 
Matsuura, M. 1991. Vespa and Provespa. P. 232-262. In: Ross, K.G. \& Matthews, R.W. (Eds). The social biology of wasps. Cornell University Press, Ithaca and London. $696 \mathrm{pp}$. DOI: https://doi.org/10.7591/9781501718670

Matsuura, M. \& Yamane, Sk. 1990. Biology of the vespine wasps. Springer-Verlag, Berlin. $323 \mathrm{pp}$.

Oksanen, J., Blanchet, F.G., Friendly, M., Kindt, R., Legendre, P., McGlinn, D., Minchin, P.R., O'Hara, R.B., Simpson, G.L., Solymos, P., Stevens, M.H.H., Szoecs, E. \& Wagner, H. 2019. Vegan: community ecology package. version 2.5-6. Available at: https://CRAN R-project.org/package= $=$ egan (accessed 8 September 2020).

Oyaizu, W. \& Kudô, K 2013. Seasonal changes in the number of vespine wasps and levels of parasitism by Xenos mouton (Strepsiptera, Stylopidae) collected with attractant traps in Matsunoyama forests, Tokamachi city, Japan. Bulletin of the Faculty of Education (Natural Sciences), Niigata University, 6: 49-57.

R Development Core Team. 2020. R: a language and environment for statistical computing. R Foundation for Statistical Computing, Vienna, Austria. Available at: http://www.rproject.org. (accessed 8 September 2020).

Smith-Pardo, A.H., Carpenter, J.M. \& Kimsey, L. 2020. The Diversity of Hornets in the Genus Vespa (Hymenoptera: Vespidae; Vespinae), Their Importance and Interceptions in the United States. Insect Systematics and Diversity, 4(3): 1-84. DOI: https://doi.org/ 10.1093/isd/ixaa006

Ueno, 2014. Establishment of the invasive hornet Vespa velutina (Hymenoptera: Vespidae) in Japan. International Journal of Chemical, Environmental \& Biological Sciences, 2: 220-222.

Yamaguchi, Y., Tsuchida, D. \& Kudô, K. 2015. Ant fauna of coastal area in Niigata: application of ants as an environmental education tool. Bulletin of the Faculty of Education (Natural Sciences), Niigata University, 8: 29-39.

Yamaguchi, Y., Yazawa, H., Iwanishi S. \& Kudô, K. 2009. Ant fauna in totting logs in Matsunoyama, Niigata. Bulletin of the Faculty of Education (Natural Sciences), Niigata University, 2: 27-30. 